\title{
Garden-centre valuations
}

Received: 18 August 2005

\section{Andrew M. Hamilton}

is an associate director of Hammond Phillips. Prior to joining Hammond Phillips in 1992, Andrew was a director of De Morgan Group and an associate partner of Bernard Thorpe and Partners (now DTZ).

\begin{abstract}
This paper is intended as a guide to the valuation of the newly emerging market of garden centres and their associate uses. As operational entities, garden centres are a form of retailing that is attracting the interest of institutional funds as valued forms of investment by way of sale-and-leaseback transactions.
\end{abstract}

\section{Keywords:}

garden centres, valuations, potential, investments, sale and leaseback, leisure

\section{INTRODUCTION}

The term 'garden centre' can, in effect, mean many different things. At the top of the market there are the state-of-the-art centres merchandising a wide range of products - they are both specialist retailers of garden plants and other associated products, and more general retail centres in their own right. In the middle market there are smaller centres with site areas of two to four acres, and stores specialising in DIY retail that have garden centres attached. Finally, at the other end of the scale, are the small, horticulturalbased nursery businesses that have expanded into the retail sale of their home-grown plants and associated garden products.

All in all, garden centres now provide an alternative retail leisure experience catering for a multimillion-pound market. Over the past 15 to 20 years the demand from the consumer has grown at a quite extraordinary pace to a level of sophistication not dreamed of in the 1970s. Unlike the high street, garden centres have reported consecutive year-on-year, like-for-like growth for the last 15 years. In 2003 the overall market grew by 10 per cent to $£ 5.64 \mathrm{bn}$. Garden centres are particularly affected by bad weather and this, combined with the current tough economic climate, has not helped the sector in 2005. Nevertheless, this has not stopped the larger groups recently reporting like-for-like increases over the last six months:

\section{DEVELOPMENT OF THE MARKET}

The seemingly insatiable appetite of today's consumer has to be regarded as deriving not only from the feel-good factor and a higher level of disposable income, but also from the traditional 


\section{Retail concessions}

Leases/sales \& leaseback
British passion for gardening combined with a greater time available to follow recreational activities. This is especially true of the over-50s, perhaps the most affluent economic group today. Whether the growth of garden centres fuelled the demand or the demand generated the growth of garden centres is debatable.

As such, garden centres are a conundrum. Are they retail? Or are they leisure? Or even both? Certainly some of the turnovers achieved, often many millions of pounds per site, indicate a retail use; but most customers would surely agree that this is one of the more leisurely ways to shop. Garden centres, with their associated retail units, provide a relaxed leisure experience that has a wide appeal to all generations of the shopping public. Many high-street retailers recognise the trend, and understand the importance of garden centres to the shopper. One of the real opportunities for high-street retailers is that of taking concession space as garden centres dedicate increasing areas to non-horticultural use. The Works, Ponden Mill, Natural World, Edinburgh Woollen Mill, Thorntons, Julian Graves and many others have all recognised the latent retail opportunity. There is conclusive evidence that retailers specialising in leisure and lifestyle products are finding a new and profitable sales channel through garden centres.

In the past the property industry has looked at garden centres from a redevelopment to an alternative-use perspective. Gardencentre owners appreciate how valuable their sites are and, in most cases where sites are large, the existing-use value as a garden centre is probably as high as, if not higher than, many alternative uses.

The property industry is now looking at the garden-centre sector for what it can offer in its own right. Demand is there, but supply is slow. Many garden-centre groups are looking to expand across the country. Dobbies has just announced four new sites, while another plc, Blooms of Bressingham, has recently opened two new state-of-the-art centres at Gloucester and Rugby. The former project is a sale and leaseback, which must surely be one of the future routes for garden-centre expansion, enabling the property sector to work alongside garden centres.

Suitable sites are slowly emerging. In Spalding, Thornfield Properties has a 30,000-square-foot garden centre as an anchor tenant to its unique and successful Springfields Outlet Shopping and Festival Gardens destination. In Stoke on Trent, St Modwen Properties and leisure entrepreneur Willi Reitz are implementing a $£ 100 \mathrm{~m}$ regeneration project at Trentham with a large 60,000 -squarefoot garden centre as an anchor tenant for its retail mall and rejuvenated gardens. Dobbies will shortly commence a 100,000square-foot development in south Sheffield, while Blooms is developing 100,000 square feet on a 26-acre site adjoining Bicester Outlet Village.

It is envisaged that leasing will become increasingly common within the garden-centre industry as leasehold centres become recognised as viable alternatives to the established freeholds. In 
Valuation

\section{Valuation experience}

Turnover particular, sale and leasebacks, which can enable freehold operators to release capital while continuing to run and own the business, are attracting more interest. More second-generation, privately owned garden centres are seeking to release capital by this method. A recent sale-and-leaseback transaction has been completed at Gloucester on behalf of Blooms, where planning permission was obtained for the total redevelopment of an old, established garden centre providing approximately 65,000 square feet of new accommodation. This has been successfully sold on to a major fund represented by LaSalle Asset Management as a sale and leaseback based principally on the trading performance of the centre itself.

Valuations of these properties, quite clearly, have to adjust correspondingly to keep pace with the sophistication of the industry. Today the vast majority of garden centres are still owner-occupied, with only a few examples of leasehold transactions being undertaken.

\section{VALUING GARDEN CENTRES}

In considering the valuation approach, it is necessary to refer to Guidance Note 1 of Part 4 of the RICS Appraisal and Valuation Standards, Fifth Edition (the Red Book). ${ }^{1}$ The valuation of all operational entities is made up of two distinct parts:

- the land and buildings

- the market perception of the trading potential, excluding personal goodwill.

It is not necessary to refer in detail to all the guidance notes, but it is important to highlight certain topics.

The valuation method adopted by a valuer must reflect the approach generally used by the market and be similar to other commercial property. This would usually be by analysis of comparable transactions. Accordingly, the valuer must have firsthand experience of such comparisons, probably gained by openmarket sales. This experience, if it is to be of any use in drawing a correct comparison, will include a detailed study of the trading accounts as well as a knowledge of merchandise ranges and business mix, relevant planning history and any other information. It should be emphasised that goodwill can only have a market value if it is transferable. This is different to the value attributable to trading potential.

Turnover is one of the key factors in determining value, but maximising turnover does not always mean that the maximum price has been achieved: purchasers will not want to see sales that have been increased as a result of eroded margins. If that happens they will apply a discount. The amount of that discount depends upon the extent they believe sales will fall away if and when prices are raised to recover margins. It can be seen, therefore, that it is essential the valuer has detailed knowledge of current trends and market requirements. 


\section{Potential}

\section{Determining factors}

Traditionally the three most important factors affecting property values are location, location, location; but for garden centres it might equally read potential, potential, potential. Over the last 12 months garden centres have been concentrating just as much on developing out and improving existing centres as they have on acquisitions. This is as much a result of the tightening of the UK planning regime as it is of the availability of suitable sites.

Factors determining value are fairly numerous. The following are considered to be key:

- catchment population within a defined area

- population demographics

- competition

- accessibility

- site size

- building quality and size

- catering provided

- existing net profit.

\section{Catchment population}

The average successful garden centre needs an adult population of approximately 250,000 within a 20 - to 30 -minute drive. Certain large regional centres, however, rely on much longer drive times up to 60 minutes could be appropriate, depending on what competition there is in the region.

\section{Population demographics}

By their very nature, garden centres cater for the needs of houseowners with the means of travel. Social grading, car ownership and house ownership levels are all to be considered in assessing the true potential.

\section{Competition}

Even in the event of the population profile being strong, the potential spend per capita will be distributed between garden centres. The less competition, the greater the potential to attract a larger share of the available spend, with a corresponding increase in turnover.

\section{Accessibility}

The actual location is important when compared to the competition. Principal trunk-road situations with good entry and exits will always be more appealing to the shopping public. Main trunk routes of dual-carriageway standard with access from a roundabout are regarded as the best, grading down to a B road or country lane.

\section{Site size}

In assessing a site it is necessary to consider both the existing 
turnover and the potential on offer. A site that has the ability to allow further development, together with improved car parking and overflow parking, will have greater potential than a site that is too small or which has already developed to its maximum capacity.

\section{Building size}

The quality, design and age of the main retail area are important considerations. There are many differing designs and standards, with older buildings rarely lending themselves to adaptation to modern-day retailing standards.

A successful garden centre is made up of a range of retail and display elements, which should be in a suitable proportion to each other. Such elements include:

- main heated retail sales area

- catering

- unheated sales area

- external covered sales such as polytunnels

- planteria

- other ancillary floor area

- growing nurseries

- main car park

— overflow car parking.

Each element will contribute to turnover in different proportions. For example, the main covered retail sales area may generate in excess of $£ 100$ per square foot, while the planteria will contribute only $£ 25$ per square foot. Consequently, a zoning method is adopted in calculating the combined building value. Each element is ranked as a percentage of the main retail sales area - 'in terms of main retail' (ITMR). By using this method, comparable transactions can be calculated on a rate-per-square-foot basis.

\section{Catering}

Catering in garden centres is a massive growth area. Larger garden centres are targeting $£ 1 \mathrm{~m}$-plus from catering, often from more than one restaurant. For example, Blue Diamond has a silver-service restaurant at its new Trentham Gardens centre, as well as a selfservice café and a separate coffee-lounge area.

As one of the fastest-growing amenities over recent years, catering facilities can and do contribute substantially to the overall turnover, as well as adding to the dwell time in the centre. The seating capacity and potential for improvements are important factors. For example, an average factor of five to one cover per 650 square feet ITMR is recommended.

\section{Net profit}

In the assessment of garden centres it is necessary to look closely at the last three years' accounts and to form a judgment on the 


\section{Gross/net margins}

\section{Concession income}

underlying net profit generated from the turnover. Many operational centres are run by small family businesses or independents which incur higher levels of expenditure on overheads than would be expected by a larger group. These chain operators have the benefit of central purchasing power and smaller on-site management costs. It is therefore necessary to understand accountancy procedure and be prepared to adjust where appropriate.

Gross margins vary, but the norm is to be expected at around 42-47 per cent, while the net profit before tax could be expected to be $12-18$ per cent. In any open-market valuation the underlying adjusted net profit should not be ignored, despite the valuer's views on potential. Whatever the potential, it will not be achieved overnight, so if funding is required the underlying secure profit or surplus will be important.

The final piece to this complicated jigsaw is concession income. Many garden centres, whether independently run or part of a chain, will incorporate concessions on site to complement their own trade with specialist operators. Such concessions may be catering, aquatics, pets, conservatories, garden sheds and greenhouses or even swimming pools and landscape designers. There has, however, been a tendency over recent years for some of these to be taken inhouse to take advantage of the profit margins offered.

Where concessions are granted they are invariably either on licences or short-term leases outside the provisions of the Landlord and Tenant Act 1954. All the same, they are more often than not granted to individuals with little covenant strength. The income generated is therefore risky, with little or no chance of debts being recovered should they arise. While such concessions add value, the income generated needs to be valued as a high risk.

\section{VALUATION PROCEDURE}

Having now summarised the general methodology of comparison, one can turn to the valuation procedure. As highlighted at the beginning of this paper, a valuation of an operational garden centre is made in two parts:

- land and buildings

- the market perception of the trading potential, excluding personal goodwill.

\section{Freehold land and buildings}

As in most other commercial valuations, land and buildings are assessed on a yield multiplier of a notional rental value. The assessment of a notional rental value is not, however, as clear-cut - there remain only a very few leasehold open-market transactions from which to draw comparisons. In the analysis of open-market sale transactions this model uses a notional rental based on formulae that have been found to be generally acceptable to the main operators. 
The yield element is governed by average factors reflecting the quality of the location, site and buildings. The yield is a reflection of the industry's demand, which may vary from region to region and according to the quality of the competition, to make acquisitions in any one location.

\section{Trading potential}

This element of the valuation is considered in the light of the past three years' accounts, and the opportunity for a reasonably competent operation to improve the turnover. The valuer should be able to draw on experience to assess the potential turnover expected from either better management, improved retail skills, enlarged merchandising range or, more importantly, refurbishment or even enlarging the retail sales area by extensions if the site area allows.

\section{CONCLUSION}

In conclusion, the garden-centre market is an emerging opportunity that does not seem to be quite so adversely affected by the current downturn on the high street. While displaying many of the attributes of other types of commercial property, garden centres have their own individual characteristics that make the process of valuation somewhat different to other parts of the retail sector. Consequently, specialist skills and an in-depth knowledge of the garden-centre market are required if valuations are to be made accurately and effectively.

\section{References}

1. Royal Institution of Chartered Surveyors (RICS) (2003) Red Book: RICS Appraisal and Valuation Standards, RICS, London, UK. 